\title{
IMAGENS E MEMÓRIAS DO BAIRRO DO RECIFE
}

\author{
Sandra Simone Moraes de Araújo ${ }^{1}$
}

\section{Introdução}

Imagens e memórias são categorias que motivam esta pesquisa ${ }^{2}$. Seu objetivo consiste em construir uma narrativa por meio das imagens mnésica e iconográfica sobre as mudanças na paisagem do Bairro do Recife, estabelecendo as relações entre os antigos e novos usos dos lugares e os impactos para a população local. A ideia de realizar esse estudo, partiu da observação empírica, por meio da qual foi percebida as transformações das ruas, praças, avenidas e casarios desse bairro, na tentativa de requalificar o uso desses espaços e torná-los parte das práticas do cotidiano da cidade do Recife.

É uma pesquisa que se desenvolve a partir do entrecruzamento das imagens antigas - que hoje fazem parte do acervo iconográfico do Museu da Cidade do Recife e as fotografias realizadas durante o trabalho de campo, dos novos cartões postais e das imagens reveladas nas narrativas de frequentadores do Bairro do Recife.

As narrativas são imagens construídas pelas experiências individuais e coletivas do narrador e convidam os leitores a percorrerem a cidade através das lembranças das "ruas, becos, calçadas, pessoas, brigas, amores, família, trabalho... onde se encontram as suas dúvidas, respostas, alegrias, seus anseios e o seu futuro" (Nogueira, 1998: 117, 118). As imagens mnésicas entrelaçam o invisível e o visível, o vivido e o imaginado e se entrecruzam com as imagens impressas (pinturas e fotografias) que preservam fragmentos do passado.

Peter Burke (2017) considera o uso da imagem, seja ela uma pintura ou uma fotografia, um importante instrumento para o conhecimento dos espaços da cidade. As imagens revelam as modificações ou permanências da paisagem no transcurso do tempo. Imagens antigas de um lugar podem também ser consideradas como estímulos para as lembranças de indivíduos e grupos contarem as suas histórias e muitas vezes são

\footnotetext{
${ }^{1}$ Universidade de Pernambuco, Brasil. Email: $\underline{\text { sandrasimonema@gmail.com }}$ ORCID id: https://orcid.org/0000-0001-7923-2194

${ }^{2}$ Essa pesquisa teve início em 2018 e parte do seu conteúdo foi apresentado e publicado nos anais da 18 th IUAES World Congress e na XIII Reunião de Antropologia do Mercosul. Nesse sentido o texto deste artigo se mistura elementos que foram apresentados nos referidos congressos.
} 
usadas para a reconstrução ou restauração de monumentos, lugares etc., a exemplo da cidade de Varsóvia que após a segunda guerra mundial foi reconstruída "com base no testemunho de materiais impressos e também de pinturas de Bernardo Belloto (Burke, 2017: 129).

A imagem retratada por um artista plástico ou feita por meio de uma câmera fotográfica, como diz Kossoy (2014), é um elemento fundamental de fixação da memória, visto que ela fixa na seta do tempo a paisagem, os comportamentos, os elementos simbólicos de uma época e lugar e se convertem em arquivos da cultura. Neste sentido, conhecer o Bairro do Recife por meio das velhas e novas imagens pode nos levar a refletir sobre as mudanças e usos dos lugares da cidade, bem como lançar questões sobre o desafio de preservar um lugar que em 1998 foi considerado pelo Instituto do Patrimônio Histórico Artístico Nacional (IPHAN), por meio dos registros 119 do Livro Arqueológico, Etnográfico e Paisagístico e 614 do Livro de Belas Artes, um Conjunto Arquitetônico e Paisagístico Nacional.

Como um patrimônio cultural, esse bairro deveria ser um lugar de memória, guardião da gênese da cidade, no entanto as transformações realizadas no decorrer da história deixam vestígios que podem ser interpretados sobre a égide dos interesses de exploração econômica em detrimento à preservação da história e da identidade cultural desse lugar.

\section{Novas e velhas imagens do Bairro do Recife}

Em Marília o viajante é convidado a visitar a cidade ao mesmo tempo em que observa uns velhos cartões postais ilustrados que mostram como esta havia sido (...). A velha Marília provinciana, não restituem uma certa graça perdida, a qual, todavia, só agora pode ser apreciada através dos velhos cartões postais. (Calvino, 1990: 30)

Como em Marília, cidade narrada por Marco Polo ao Grande Kublai Kan, no Bairro do Recife os moradores e visitantes são convidados a conhecer dois bairros, um antigo que se encontra nas lembranças de seus frequentadores e nas velhas fotografias, e outro que se mostra a partir do entrecruzamento do passado com o presente. Os antigos casarios erguidos pelas ocupações holandesa e portuguesa no período colonial, se misturam aos modernos edifícios construídos nas primeiras décadas do século XX e desenham a paisagem de um lugar que em outrora era apenas uma faixa de terra conhecida pelo nome de Arrecife dos Navios (figura 1). 
Era no Arrecife dos Navios onde se encontrava um porto por onde saía, com frequência, toneladas de açúcar produzido por meio do suor, sacrifício e sofrimento dos escravos e escravas africanas que nesta terra eram forçados a trabalhar. $\mathrm{O}$ açúcar era no século XVII objeto de cobiça dos muitos povos do velho continente e foi justamente por causa dele que os holandeses ocuparam, entre 1630 a 1654, as terras do Recife e aqui instalaram a Nova Holanda.

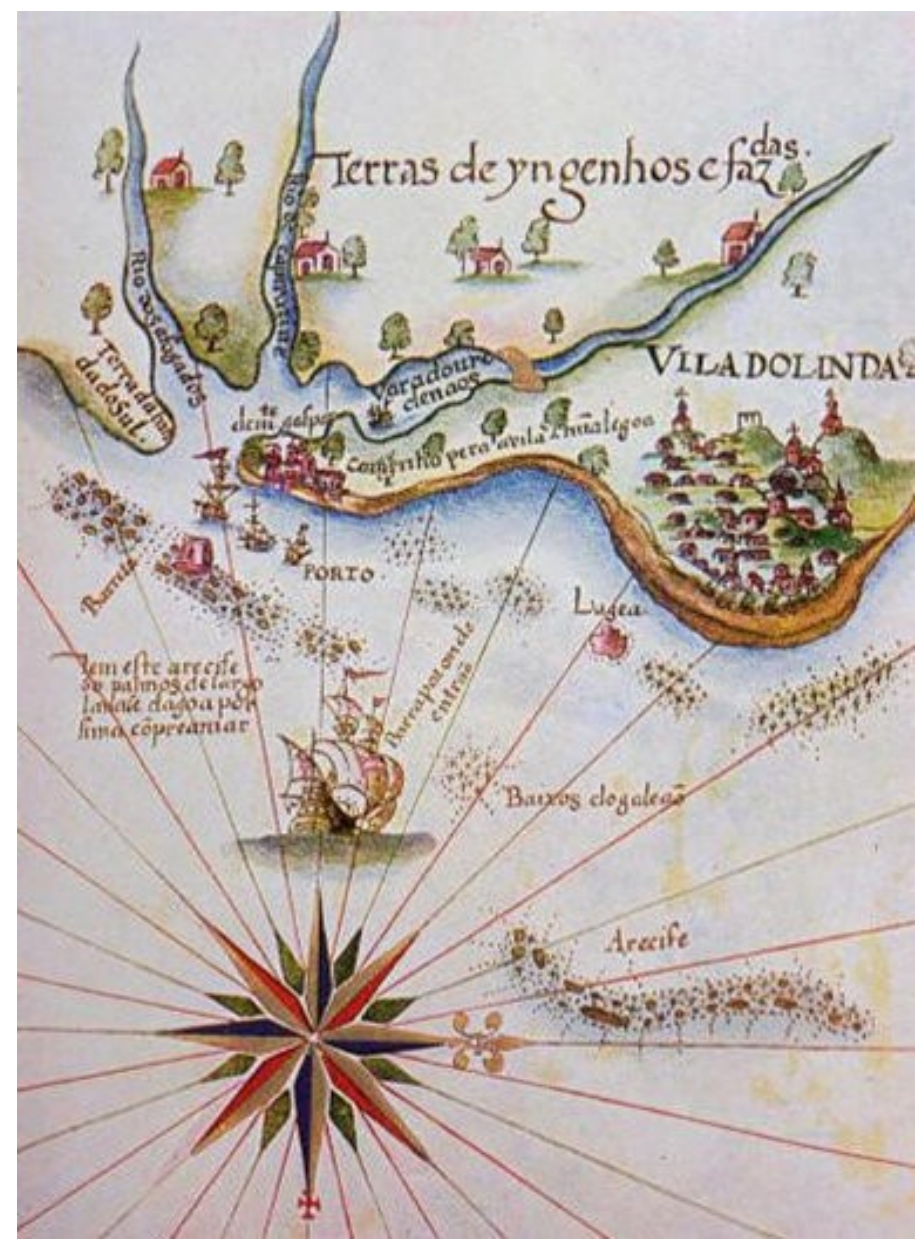

Figura 1 -Mapa da Vila de Olinda e do Arrecife do fim do século XVI Fonte: Prefeitura do Recife - http://www2.recife.pe.gov.br/pagina/hisoria

Quando esses recém-chegados pisaram nessa terra, já existia a Vila de Olinda, fundada por Duarte Coelho durante o século XVI. Construída em cima de morros (figura 1), a topografia desta Vila desapontou o olhar dos holandeses: "Ninguém que da Holanda vier aqui quererá ir morar em Olinda". Embora esses "estrangeiros" percebessem certa beleza na paisagem natural de Olinda, consideravam que a sua

\footnotetext{
${ }^{3}$ Trecho da Carta de Adolph Van Els aos diretores da Dordrecht em 5 de abril de 1630. (NETO, J. A. G M. Apud CASTRO, J. 1955: 87)
} 
topografia inviabilizava uma defesa eficaz. Mas, "se a cidade é uma criação da vontade humana, essa vontade só se concretiza quando corresponde a satisfação de necessidades materiais ou psicológicas de caráter coletivo" (Castro, 1954: 78). Neste sentido, se os holandeses viviam numa cidade anfíbia, construída em depósitos aluviais provenientes da fusão de rios, foi na paisagem constituída pelo encontro dos rios Beberibe e Capibaribe e a presença do porto, onde esses recém-chegados encontraram um lugar próximo a sua experiência cidade.

Como observou Josué de Castro (1957), foi a partir da experiência de viver numa cidade anfíbia que os holandeses rejeitaram a Vila de Olinda. Para edificar a Nova Holanda era preciso encontrar um lugar próximo à experiência de cidade de seus fundadores, e foi no fragmento de terra conhecido como Arrecife dos Navios que os holandeses reconheceram a paisagem de sua cidade natal. "Como comenta Ítalo Calvino (1999), "há sempre algo em uma cidade que se encontra em outras, neste caso, ambas se revelam em seus espelhos d'água" (Figueiredo; Araújo, 2012: 356). Amsterdã, uma cidade portuária cortada por rios e canais e o Recife um lugar atravessado pelos rios Capibaribe, Beberibe e o Oceano Atlântico (Figura 2).

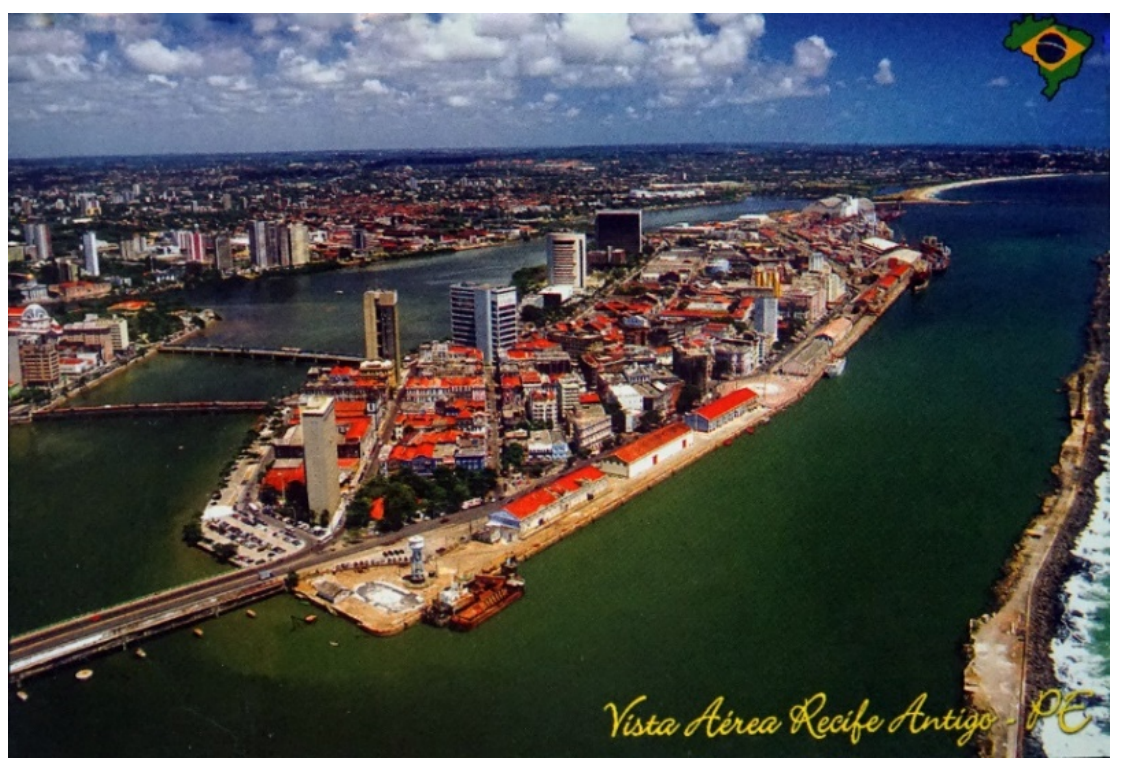

Figura 2 - Vista Área do Bairro do Recife - Recife-PE Cartão Postal Atual

O Arrecife dos Navios de antes, atualmente, é conhecido como Bairro do Recife. Desse fragmento de terra a cidade do Recife se expandiu para outras ilhas que aos poucos foram interligadas por pontes (figura 2). Hoje com 482 anos de história, essa cidade ainda é ponto de encontro de diversas etnias e nacionalidades tais como: judeus, africanos, flamengos, neerlandeses, portugueses, dentre outros, pessoas de diferentes 
crenças, hábitos, visões de mundo. "Sua cultura é resultado da mistura dessa diferença, e assim, o Recife se multiplica em infinitas cidades: dramática, mal-assombrada, romântica, de crimes, das serenatas de rapazes, pelo Capibaribe, nas noites de lua". (Freyre, 2007: 24.)

Nas histórias narradas por Gilberto Freyre, o Recife é uma cidade assombrada por contos e crenças de acontecimentos antigos. Nos versos de João Cabral de Melo Neto, o Recife é passado "pelo rio como uma rua é passada por um cachorro; uma fruta por uma espada. O rio ora lembrava a língua mansa de um cão, ora o ventre triste de um cão, ora o outro rio de aquoso pano sujo dos olhos de um cão." ${ }^{4} \mathrm{Na}$ música de Chico Science é a "cidade do mangue. Incrustada na lama dos manguezais. Onde estão os homens caranguejos. Minha corda costuma sair de andada. No meio das ruas e em cima das pontes."

Na poesia, na música, nos contos de assombração e na literatura o Recife é real, imaginado e desejado por muitos de seus habitantes e a cidade mental, transcrita nos versos, prosas ou narrativas da memória de seus transeuntes ultrapassam o empirismo da cidade concreta e constrói e reconstrói a sua paisagem, mesmo quando esta, ao longo do tempo, tenha sido modificada por grandes reformas, como ocorreu, dentre outros lugares desta cidade, no Bairro do Recife.

Nesse bairro ainda é possível encontrar os vestígios da arquitetura do seu primeiro traçado urbanístico que foi projetado e desenvolvido pelos holandeses no século XVII. Atualmente, restam poucos casarios e ruas construídas no período do Brasil holandês, isto porque, da primeira década do século $\mathrm{XX}$ aos nossos dias, os frequentadores deste bairro assistem as mudanças, ora provocadas pelos desgastes do tempo, ora pelas ações antrópicas realizadas por meio de reformas e requalificação dos espaços do Barrio Recife.

A primeira reforma foi inspirada na arquitetura da Paris de Haussmann (figuras 3, 4 e 5), o espaço onde existiam as ruas estreitas deu lugar as largas avenidas, resultado da demolição de aproximadamente $2 / 3$ do Bairro "e os antigos sobrados coloniais foram substituídos por edifícios ecléticos. O cunho paisagístico e esteticista de tal reforma foi verificado na valorização das fachadas (...) e construção de edifícios imponentes (IPHAN, 2010: 4).

4 Cão sem plumas - poesia - João Cabral de Melo Neto. Disponível em https://escolaeducacao.com.br/poemas-de-joao-cabral-de-melo-neto/. Acesso 01/06/2019.

${ }_{5}^{5}$ Antene-se - Música de Chico Science. Disponível em https://www.letras.mus.br/chico-science/304728/. Acesso em 01/06/2019. 


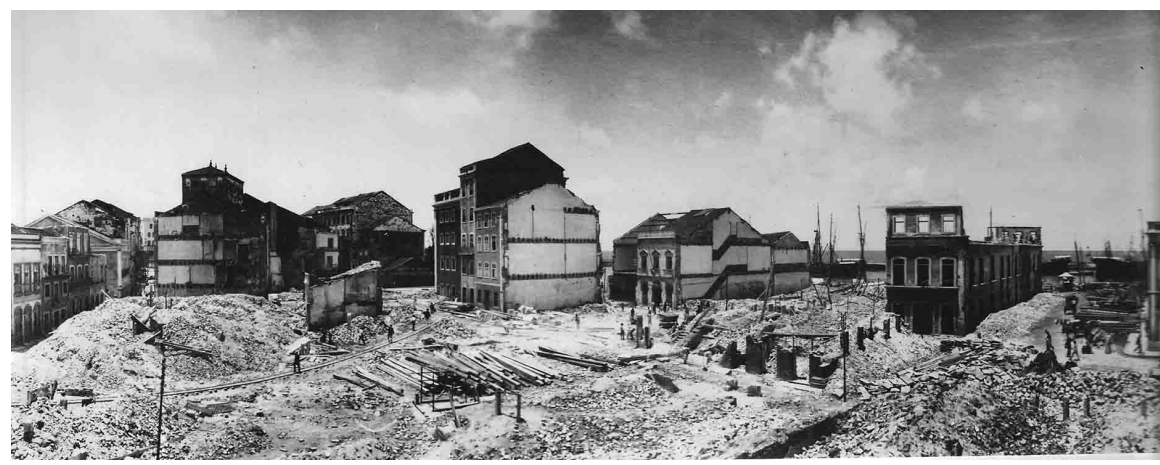

Figura 3 - Demolição do Bairro do Recife durante a primeira reforma Fonte: Acervo do Museu da Cidade do Recife

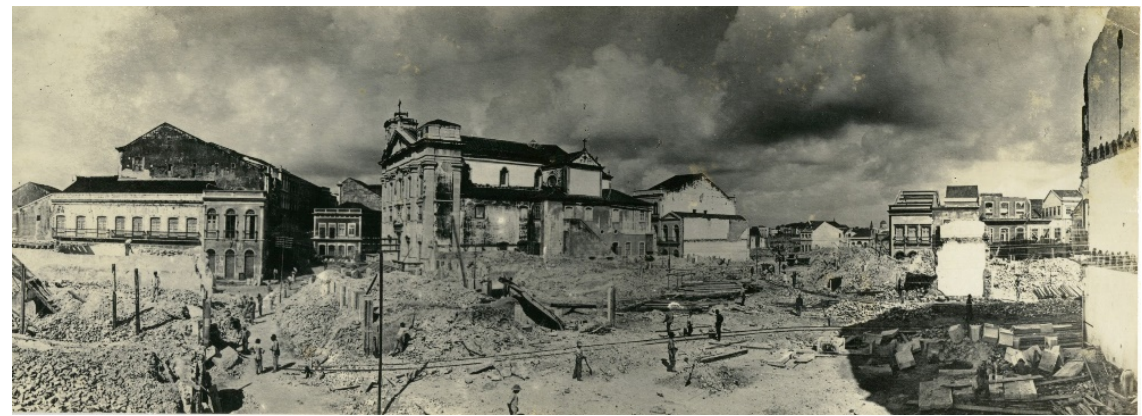

Figura 4 - Demolição do Bairro do Recife - Igreja do Corpo Santo - primeira reforma Fonte: Acervo do Museu da Cidade do Recife

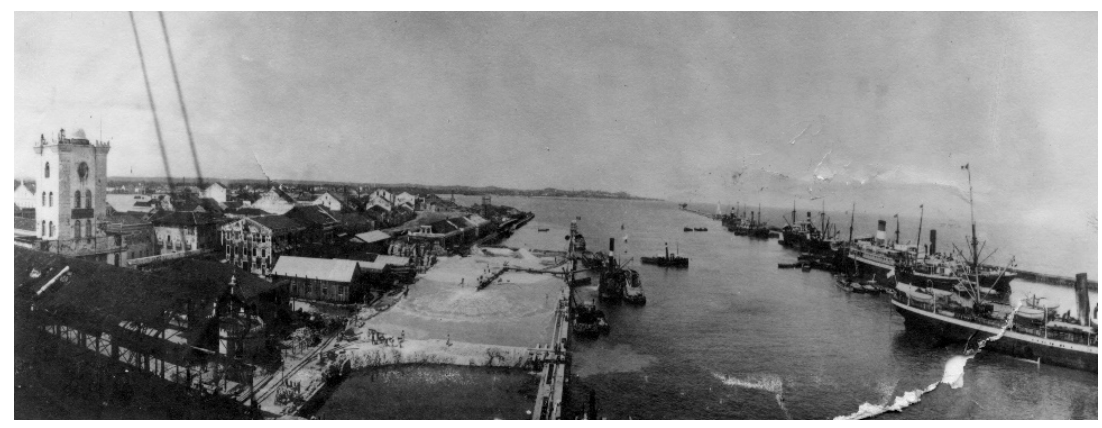

Figura 5 - Reforma do Porto do Recife - primeira reforma Fonte: Acervo do Museu da Cidade do Recife

Essa reforma foi imposta sob a égide do discurso da modernização e salubridade ao destacar a importância de erradicar as habitações que possuíam grande número de moradores, com poucos cuidados com a higiene e um precário cuidado com os dejetos. Eram considerados locais de disseminação de doenças tais como: desinteria, varíola e gripe, além da proliferação da sífilis nos prostíbulos. Nessas moradias se encontravam grande parte de mascates, artesãos, marinheiros e prostitutas, "em seu lugar, o Bairro do Recife passou a abrigar bancos, empresas de importação e exportação, associações 
comerciais, firmas de crédito. Não é por acaso que o primeiro imóvel erigido (...) foi o London and Brazilian Bank"6.

Após essa reforma, durante boa parte do século XX, o Bairro do Recife viveu dias de glorias e derrotas, sendo lugar de expansão do enriquecimento de grupos econômicos, de trânsito de fidalgos e de gente elegante que frequentava o Hotel Chanteclet, mas que, simultaneamente, dividiam o espaço com prostitutas, mendigos e pescadores que ainda, de uma jeito ou de outro, permaneciam pelas ruas do bairro, e sem perceberem, denunciavam as contradições inerentes ao próprio capitalismo.

A reforma realizada na primeira metade do século $\mathrm{XX}$ organizou o desenho do que hoje é o atual Bairro do Recife e o caracterizou como uma zona portuária e de transações econômicas. Foram décadas de grandes negócios, mas, nos anos 1940 “durante a II Guerra Mundial, o bairro iria sofrer outra grande transformação, tornandose na mais importante zona de prostituição da cidade; e com a decadência, perdeu o seu charme e os casarões e sobrados, em sua maioria deterioraram-se" (Braga, 2002: 28).

Dos anos 40 aos anos 90, o Bairro do Recife foi, pouco a pouco, perdendo a sua beleza e importância comercial. Alguns dos antigos prédios de luxo se transformaram em boates, cabarés e bares (figura 6). As ruas e avenidas do bairro passaram a ser percebidas como lugares de boemia e prostituição.

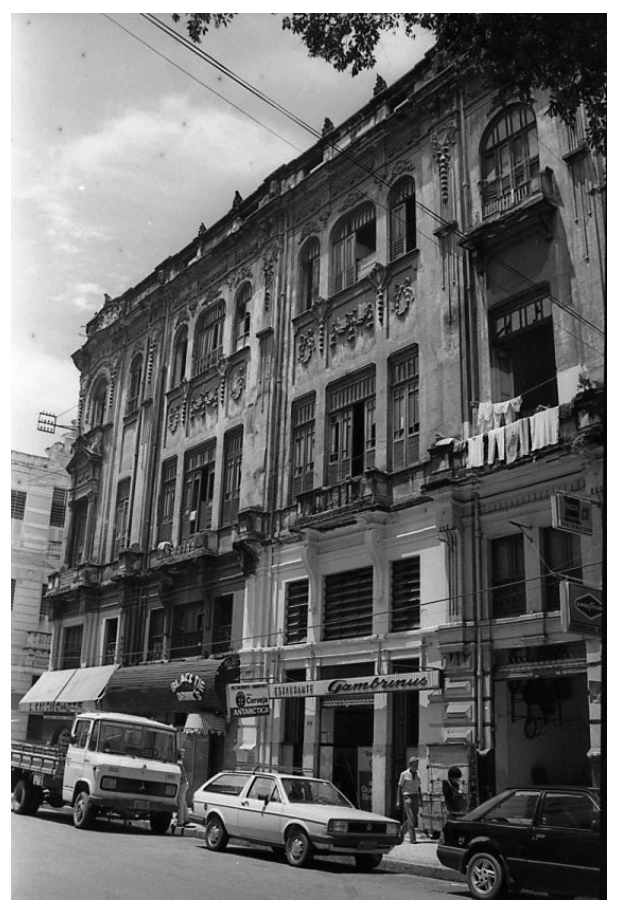

Figura 6 - Fachada dos casarios do Bairro do Recife e do Restaurante Grambrinus - 1987

\footnotetext{
${ }^{6}$ PINTO, Luiz Carlos. Bairro do Recife 100 anos depois: História de vencidos e de esquecimento. Disponível em http://marcozero.org/bairro-do_recife-100-anos-depois/
} 
Se antes, como dizia Josué de Castro, o Recife nasceu para servir ao porto, agora o que fazer se durante os anos de 1980 as atividades portuárias foram paulatinamente transferidas para o Porto de Suape? Lugar tão distante desse minúsculo bairro onde quase não se reconhece a imagem construída durante a Primeira República. Mais uma vez a má fama voltou a circular e o Bairro do Recife era visto como lugar enigmático de prostituição e assaltos. Com o objetivo de revitalizar e fazer emergir a "Belle époque" uma nova reforma foi feita nos anos noventa do século XX. A intenção foi promover o desenvolvimento econômico e turístico inspirados no modelo "gentrification". A gestão municipal da época iniciou a revitalização do Bairro com o slogan inspirado em uma obra do artista plástico Cícero Dias que diz: "Eu vi o mundo... ele começava no Recife".

$\mathrm{Na}$ perspectiva de modificar esse estigma e requalificar o uso desses espaços, em 1998, foi atribuído o título de Conjunto Arquitetônico Paisagístico a uma parte do Bairro do Recife, por conservar alguns resquícios do período holandês no Brasil e também por ser uma das poucas cidades que preserva a arquitetura da Paris de Haussmann. Na mesma década, a partir da concepção política de gentrificação, foi realizada a reforma na Praça Rio Branco, hoje é popularmente conhecida como praça do Marco Zero (figuras 7 e 8).

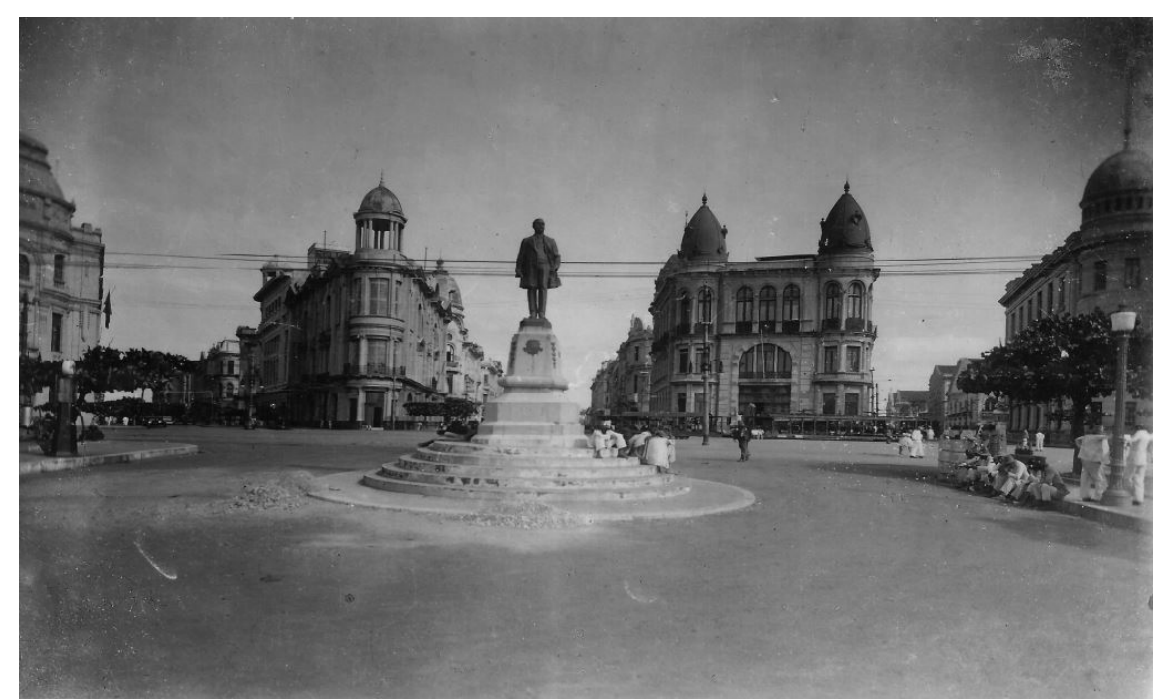

Figura 7 - Praça Rio Branco 1912

Antigo Cartão Postal do que hoje é a Praça do Marco Zero Fonte: Acervo do Museu da Cidade do Recife 


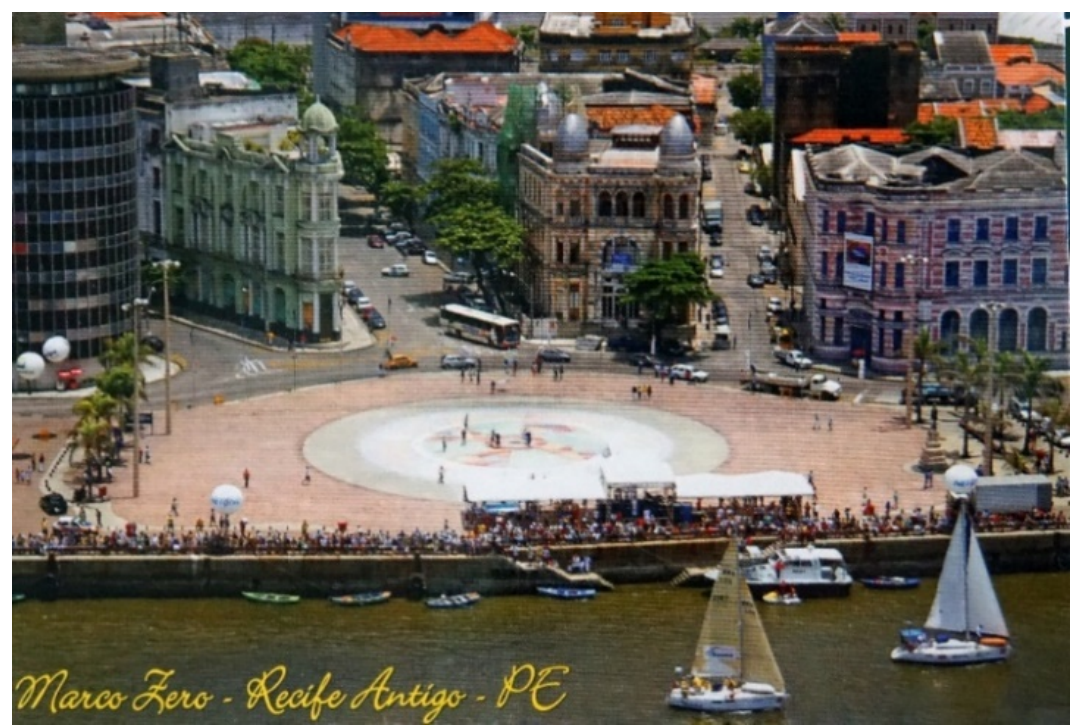

Figura 8 - Praça Rio Branco após a reforma dos anos 90, hoje conhecida como Praça do Marco Zero

Fonte: Cartão Postal - Marco Zero

A revitalização abrangeu, na sua maior parte, a Praça Rio Branco e a Rua do Bom Jesus (Antiga Rua dos Judeus) onde foram revitalizados antigos casarões e transformados em bares, restaurantes, boates etc, um polo de diversão para os turistas e as classes mais favorecidas da cidade. Não diferente da reforma anterior, as pessoas não gratas, como mendigos, prostitutas e pobres que habitavam essas ruas foram "convidados" a deixarem esses lugares, as portas, por meio das quais se controlava a entrada e saída do Recife em séculos passados, com a gentrificação, foram trocadas pelos seguranças dos lojistas e pela polícia (Proença, 2004). Nessa reforma, também foi construído sobre um antigo atracadouro, em frente à praça do Marco Zero, o Parque das Esculturas com obras do artista plástico Francisco Brennand (figura 9).

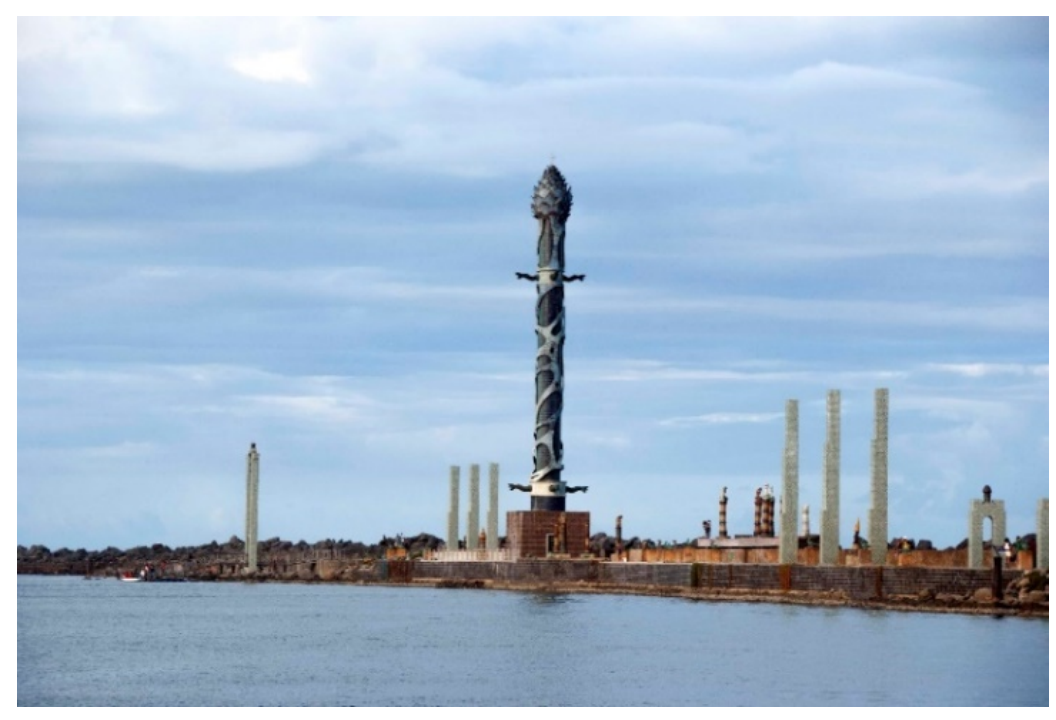


Figura 9 - Parque das Esculturas - 2015

Foto: Sandra Simone

$\mathrm{Na}$ perspectiva de antigos frequentadores do Bairro do Recife, a exemplo de Antônio ${ }^{7}$ que trabalhou em uma instituição financeira localizada neste bairro, entre os anos de 1978 a 1996. Ele assiste as mudanças e considera:

Estive presente no dia a dia do Bairro do Recife durante 17 anos, dos quais, cerca de 8 anos foram no convívio com as pessoas que transitavam na Praça Rio Branco, local este onde se concentravam os bancos públicos e privados do Estado de Pernambuco.

A reforma feita na Praça do Marco Zero, anos 90, por exemplo, não levou em consideração aspectos paisagísticos e históricos. Durante o processo de ampliação, com o objetivo de mostrar profundidade pela nova planta arquitetônica, avançou em direção ao asfalto e provocou a destruição de árvores centenárias e o parapeito que protegia o cais do porto do Recife. Em síntese, o que era belo, tornou-se uma área onde hoje prevalecem ilhas de calor. Não de calor humano, mas àquele produzido pela radiação solar incandescente que de maneira inflexível nem sequer aquece a violência urbana, a insegurança, mas se serve para saquear e lotear a cidade com arranha-céus e produz ingerência nas contas públicas, abastecendo assim a destruição de um patrimônio arquitetônico que marcou a paisagem do velho Bairro do Recife.

O investimento público e privado ainda foi direcionado para a oferta de eventos

culturais tais como: o dançando na rua, o domingo na rua, festival de seresta etc, como

maneiras de atrair a população para o bairro, uma população de fora, pertencentes as

classes sociais mais abastadas. Antônio observa:

A oferta de serviços era voltada para àqueles que possuíam poder aquisitivo elevado, pois representavam pequena parte de uma parcela que trabalhava em empresas estrangeiras ou em bancos estatais, de modo que, a maioria dos trabalhadores faziam refeições em botecos ou lanchonetes.

No edifício onde trabalhei, por exemplo, cujo apelido é 'ferro de engomar", dado o seu formato, além de sua localização privilegiada para o Marco Zero da cidade, na sua parte traseira, funcionava a famosa Galeria de Gelados e Salgados, lá podia-se tomar o melhor maltado de maneira sossegada e comer um pão com ovo na chapa e com queijo de coalho por um preço popular.

$\mathrm{Na}$ única padaria do bairro, cujo nome não me recordo, a oferta de lanches e salgados era mais ampla, assim como outros produtos, porém os preços eram indigestos, principalmente para àqueles que sobreviviam com um salário mínimo e conviviam com a inflação.

O fato de haver a presença de uma livraria no local, destoava daquilo que um bairro tido naquela época como decadente oferecia, mas a Livraria Universal provava o contrário, além de livros didáticos, também oferecia serviços de impressão e encadernação, de modo que ainda soa como algo impensável para aquele distante ano de 1978 .

As reformas que foram feitas nos anos 90 tiveram única e exclusivamente o intuito de agradar os que pretendiam investir no setor gastronômico e de serviços, os quais estavam em franca expansão na cidade do Recife. Essas transformações não beneficiaram os antigos donos de bares e restaurantes, os quais resistiram a grande deterioração persistente e violenta até os dias de hoje.

\footnotetext{
${ }^{7}$ Pseudônimo, um artifício para resguardar a confidencialidade da pesquisa.
} 
Assim, tiveram que fechar suas portas; lojas como a Livraria e Papelaria Universal, as Galerias, local onde se podia tomar o melhor leite maltado da cidade; o restaurante Gambrinus (Figura 6), Bar, Waldemar Drinks, etc. Portanto, quem não se moldou a "modernidade", de acordo com a nova política definida pela gestão pública foi perdendo cada vez mais seus espaços comerciais e, sem investimentos e com a diminuição dos clientes, somando a isso todo um processo de descaracterização onde o velho já não serviria mais. A medida que os frequentadores desses espaços foram afastados, sequer os tradicionais comerciantes ousaram resistir a tamanha transformação. Se por um lado a ideia de revitalização do Bairro do Recife, no qual os comerciantes tiveram facilidades e incentivos para que se estabelecessem, a Comunidade do Pilar - conjunto de barracos existentes próximo ao Bairro do Recife - não teve a mesma sorte; esquecida estava e assim permaneceu. A tentativa de transformar o Bairro do Recife tal qual numa Cartagena das Índias, estava fadada ao fracasso. Esse antigo bairro, local onde o sistema financeiro outrora esteve presente com seus bancos, bolsa de valores, empresas de navegação marítimas de exportação e importação; de distribuição de produtos e ofertas de serviços nas mais diferentes áreas, sucumbiu e também afetou os sonhos daqueles que utilizavam os espaços das ruas como um meio de sobrevivência ao ocupar os espaços públicos, não como lazer, mas como exercício do subemprego em busca de sua sobrevivência.

Apesar da reforma do Bairro do Recife, nos anos 90, e a implementação do modelo de gentrificação, os casarões que abrigaram os bares e restaurantes foram mais uma vez abandonados e suas fachadas paulatinamente perderam o colorido. A nova funcionalidade da rua do Bom Jesus sobreviveu alguns anos, até que, com a mudança da gestão municipal em 2000, emergiram novas negociações do uso dos espaços do bairro, seja da rua Bom Jesus, na qual os bares e restaurantes não resistiram ao pouco incentivo da gestão atual e encerraram suas atividades, seja na Praça do Marco Zero que passou a ser mais utilizada para eventos e grandes shows em diversas datas do ano, em especial no carnaval.

Foi também nos anos iniciais do século XXI que outras partes do bairro foram modificadas, a exemplo da construção do século XVIII onde funcionou até 1826 o Convento dos Padres da Ordem de São Felipe Néri (Convento dos Oratorianos), quando passou a ser sede da Alfândega. Na segunda década do século XX suas estruturas foram degradadas devido a um incêndio e tempo mais tarde foi transformado em armazéns, estacionamento e local de eventos para diversos grupos populares, a exemplo do Mercado Pop. Em 2003, neste local, foi inaugurado o shopping Paço Alfândega (figura 10) que funciona até nossos dias, sobrevivendo com poucas lojas, banco e praça de alimentação. 


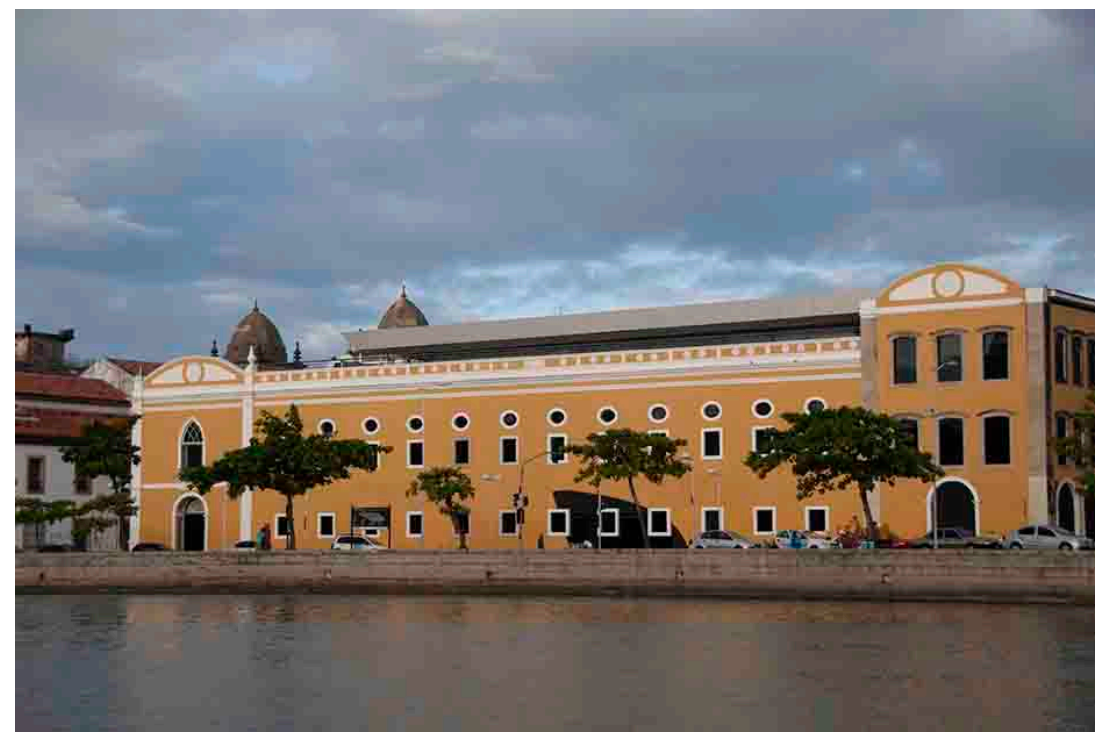

Figura 10 - Shopping Paço Alfandega - 2009

Foto: Sandra Simone

Assim se passaram os anos e mais uma vez, ao mudar o projeto partidário da gestão municipal, em 2014 foi anunciada mais uma reforma no Bairro do Recife. A Avenida Rio Branco foi fechada para o trânsito de veículos com o propósito de transformá-la em uma alameda, sendo inaugurada em 2018. A reforma substituiu o asfalto por granizo de cinza claro, nivelando-o com o piso da Praça do Marco Zero (figura 11), também foi feito o embutimento da fiação elétrica. Já os antigos armazéns localizados na Praça do Marco Zero foram transformados em um polo gastronômico e de venda de artesanatos (figuras 12 e 13).

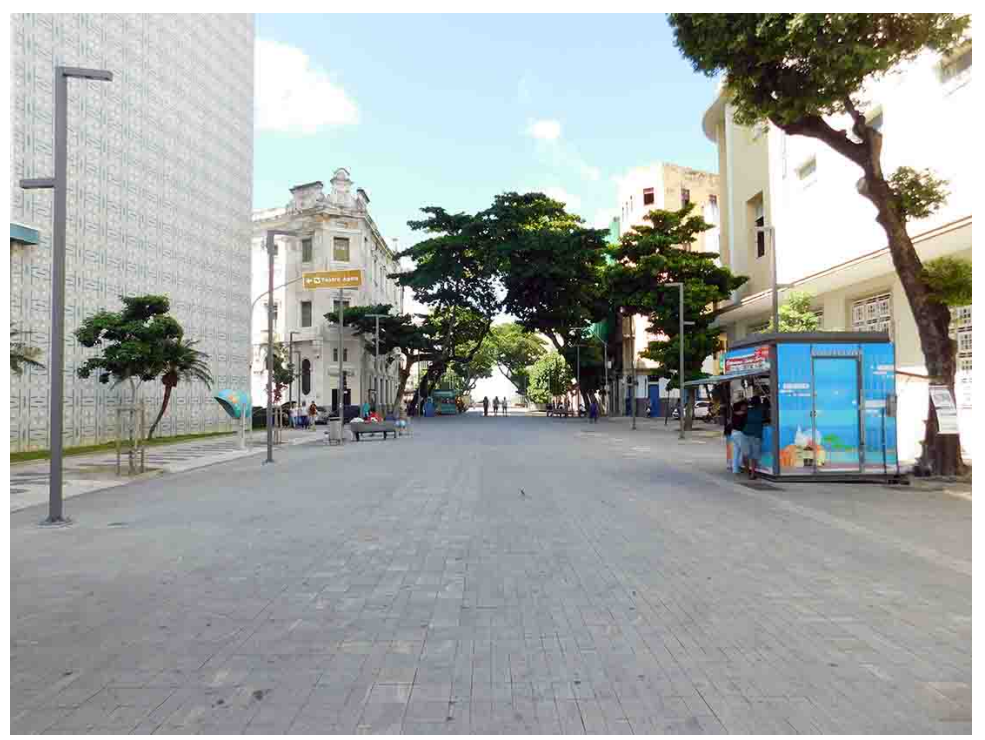

Figura 11 - Avenida Rio Branco - 2019 


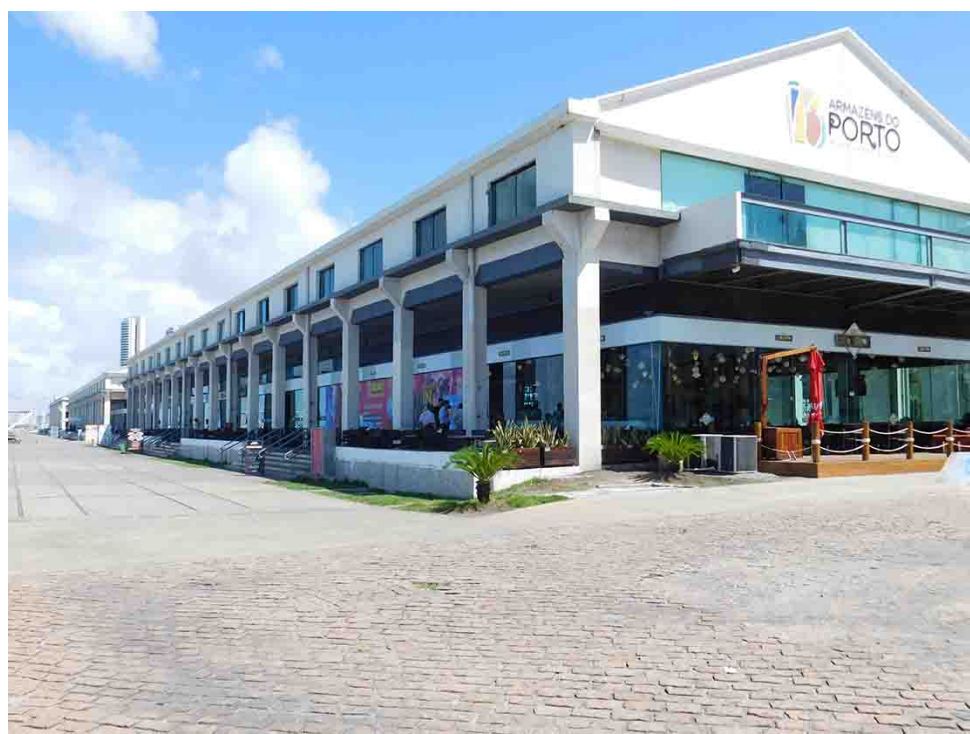

Figura 12 - Armazéns do Antigo Porto - 2019 Foto: Sandra Simone

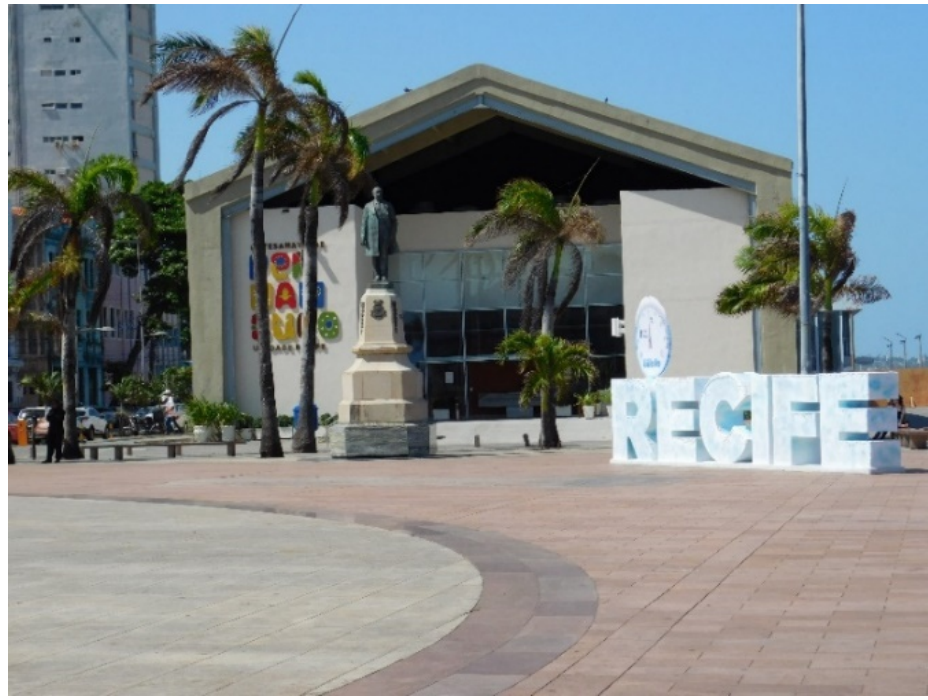

Figura 13 - Armazéns do Antigo Porto 2019 Foto: Sandra Simone

As mudanças no contexto da cidade, muitas vezes são necessárias para acompanhar novas necessidades dos seus habitantes, também com o passar dos anos os lugares são ocupados e ressignificados de acordo com a visão de mundo das novas gerações, mas o que vemos na cidade do Recife é que, a população não tem o direito de opinar sobre projetos de reforma e deixa transparecer que o uso dos espaços e suas transformações ocorrem de acordo com a vontade política de quem ocupa a gestão pública municipal. 
No Recife, em especial no Bairro do Recife, para além das fotografias antigas, as narrativas dos transeuntes revelam muitas cidades em uma só, pois, a "memória é solta, atrela-se apenas ao desejo (...), ao rememorar o narrador revê não as coisas em si, mas os significados das coisas. (Nogueira, 1998: 116,117,118). Como diz Antônio:

Ao longo dos 17 anos em que trabalhei no setor bancário, exerci minhas atividades nos mais diversos horários permitidos pela legislação. As pontes me levaram longe, mas nunca deixaram algo em definitivo em minhas lembranças, apenas divagações. Nem sei ao menos quantos passos tive que dar e no final das contas poder relatar todo o cotidiano que existiu no antigo Bairro do Recife, mas até onde pude perceber, tal como os rios Capibaribe e Beberibe, as vagas memórias me guiam em direção àquelas intermináveis lutas dos trabalhadores do setor bancário que empreendiam em busca de melhores salários e condições de trabalho.

O grande adensamento dos bancos ao longo das ruas Madre de Deus, Marques de Olinda e Avenida Rio Branco, registraram naquela época, durante o período de dissídio coletivo de algumas categorias, a grande luta entre o capital e o trabalho. A violência contra a classe trabalhadora portuária, ainda que em menor grau, também era marcada pelos conflitos entre patrões e empregados, ao passo que a violência urbana tipificada naqueles que sobreviviam a margem da inserção social, nem sequer era percebida e era tida como parte do cotidiano daquele bairro esquecido pelo poder público e por estar sempre associado ao grande capital passava a ser o grande mentor da destruição do patrimônio da cidade.

Tentar imaginar um bairro onde todos pudessem usufruir de sua beleza arquitetônica então, tornou-se uma quimera capaz de ultrapassar décadas e gerações.

A possibilidade de ir e vir e assim transitar de um espaço a outro era algo perfeitamente possível no bairro do Recife. Os poucos pedintes, eram egressos da Vila do Pilar que, com grande esforço, expressavam sorrisos no rosto assim que os navios cheios de turistas atracavam no velho cais do Porto do Recife.

Penso que talvez não sejam os locais que tenham exercido algum fascínio e sensibilizado a minha retina ou que tenha permitido que tais registros fossem povoados em minha memória, mas sim o vai e vem das pessoas abastardas social e economicamente que transitavam no local naqueles tempos e ruas que homenageavam alguns vultos de pouca ou nenhuma expressão histórica.

A presença delas circulando no bairro, denotavam a imponência e a face real e cruel dos que exerciam há séculos, a expressão máxima do poder calcado pela subserviência de um povo, de modo que essa representatividade era transmutada em atos, a exemplo do pároco da igreja da Madre de Deus, ao divulgar eventos pagos pelos representantes do poder local, ordenava o fechamento da rua Madre de Deus, até mesmo quando se se tratava apenas da celebração de alguma missa solene de trigésimo dia e que via de regra tinha encerramento regado pelo vinho francês e salgados portugueses.

Outro fato que, além de pitoresco e discreto, era quando um empresário local, então guiado pelo seu motorista particular, acessava com seu Ford Landau, de cor preta, a sua garagem privativa as dependências do escritório central. Esse ritual se repetiu durante intermináveis tardes semanais e adentraram além dos turbulentos anos da década de 70. Acredito que a representatividade desses poucos locais estejam vinculados aos fatos que vislumbrei e que me possibilitaram traçar conexões de como o poder necessita se expor aos mais vulneráveis para assim manter sua hegemonia através das gerações futuras, muito embora esquecem que pelo fato da sociedade ter o caráter dinâmico, assim determinam que tudo o que é sólido se desmancha no ar, mas que não se aplicam, quando o despertar da consciência aos que têm seus direitos suprimidos a cada dia e conseguem se indignar da melhor forma possível. 
Dessa forma, hoje percebo que o dia a dia de quem trabalhava e não era movido ao final do expediente para o desejo etílico, resumia-se então a crer que, o que era assim, assim deveria permanecer.

As mudanças e intervenções no Bairro do Recife, promovidas pelo poder público municipal e estadual e que contemplaram, por meios sucessivos, projetos de revitalização buscaram blindar os eventos promovidos pelos abastados do açúcar, do álcool e do cimento, e com isso transportaram os que viviam abandonados nas ruas, definitivamente para dentro da escala da pobreza e da informalidade, de maneira que a violência outrora gestada se contrapõe ante o slogan retirado da obra do pintor Cícero Dias e que foi inspirado para a reforma do Marco Zero, ao mencionar: "Eu vi o mundo... ele começava no Recife". Só me resta saber então onde é mesmo que fica essa tal cidade imaginada pelo artista que meus olhos não viram, nem estão em minhas lembranças, apenas nos pesadelos.

As imagens construídas pelo narrador dão ver uma interpretação do lugar presente na sua memória que junto a outras memórias supera a condição estática da cidade concreta, neste caso, do Bairro do Recife que é múltiplo, não apenas pelas tantas reformas e requalificações de seus espaços, mas pelos trajetos percorridos pelas lembranças e interpretações de seus frequentadores. Narrar sobre o lugar, é rememorar, imaginar e denunciar os descompassos entre o rememorado, o vivido e as transformações feitas no decorrer do tempo, transformações essas que algumas vezes constrói e reconstrói suas paisagens distante do desejo de seus habitantes.

As narrativas sobre o Bairro do Recife, seja do informante ou da autora deste texto, denunciam que as consecutivas reformas parecem ser feitas a partir de um ciclo que varia entre a ascensão e a decadência voltados para os desejos do desenvolvimento econômico, sem considerar os desejos dos seus habitantes. Esses por sua vez, parecem não ter vínculos duradouros com o lugar, não se identificam com o passado longínquo no processo de construção da identidade individual e coletiva. O Bairro do Recife, desde a sua primeira reforma foi transformado num lugar de negócios e se tornou um espaço de trânsito para boa parte da população da cidade que hoje assiste cada reforma modificar os seus lugares de memória e vive "em constante tensão com o espaço narrado, algumas vezes, chegam mesmo a não compreender o que se passa ao seu lado"(Lima, 2000: 15).

Observa Rubens Alves (2012) que diferente dos eucaliptos são os carvalhos, enquanto os primeiros crescem com rapidez e a sua raiz se encontra próxima à superfície, os carvalhos levam anos para se erguerem e fincarem profundas raízes. Talvez essa metáfora possa se aplicar à preservação da memória. Há lugares onde essa memória é preservada, valorizada como instrumento da história e faz parte da identidade coletiva da comunidade. Já há outras coletividades, a exemplo da Cidade do 
Recife, nas quais os governantes destituem a sua população dos seus espaços de memória em detrimento aos interesses do capitalismo e cortam as raízes que ali estavam se acomodando. Um exemplo foi a demolição, em 1973, da Igreja dos Martírios, uma construção do século XVIII, em seu lugar foi feita a ampliação da Avenida Dantas Barreto. Em anos anteriores, para construção da Avenida Guararapes foi também demolida a Igreja do Paraíso, uma construção do fim do século XVII.

As transformações no contexto da cidade são necessárias, com o passar dos anos o uso dos lugares se modificam gradativamente pelo movimento da história, mas o que vemos no Bairro do Recife é uma população, a qual não é dado o direito de opinar nos projetos de mudança. Ela não é escutada, não é considera no processo. Cada reforma varre uma parte de sua história, restando uma paisagem da cidade que passa a ser encontrada apenas nas antigas pinturas, fotografias, cartões postais e nas lembranças dos moradores e visitantes.

A memória é pulsão importante, é intermediária entre o homem e a sua relação com o mundo, é o elo tensional entre o novo e o antigo e confronta as múltiplas histórias sobre um lugar, no caso a cidade, local de inúmeras negociações de usos e contra usos, costumes e diferenças, de desejos e interesses. Bairros antigos, como o Bairro do Recife ao vivenciar um ciclo de mudanças e permanências, a cada reforma revela a mistura de temporalidades, fazendo emergir uma urbe a partir da experiência vivida por cada transeunte e das imagens guardadas nos arquivos que ao serem abertos ainda revelam um Recife histórico, mal-assombrado, terra dos homens caranguejos, do frevo, das lutas dos trabalhadores, das múltiplas cidades visíveis e invisíveis que teimam em existir diante das reformas e transformações da sua paisagem.

\section{REFERÊNCIAS}

ALVES, Rubens. Conversas com quem gosta de ensinar. $14^{\mathrm{a}}$ ed. Campinas. Papirus. 2012.

ARAÚJO, Sandra Simone M. de. Narradores da sensivel: um estudo sobre imaginário e cegueira na cidade do Recife. Tese de Doutorado apresentada ao Programa de PósGraduação em Antropologia. UFPE. Recife. 2011.

BRAGA, João. Trilhas do Recife Guia Turístico Histórico e Cultural. Recife. 2002. 
CALVINO, Ítalo. As cidades invisíveis. São Paulo. Companhia das Letras. 1990.

CASTRO, Josué. A cidade do Recife: ensaio de geografia urbana. Rio de Janeiro. Casa do Estudante. 1957.

DURAND, Gilbert. As estruturas antropológicas do imaginário: introdução à arquetipologia geral. São Paulo. Martins Fontes. 1997.

FIGUEIREDO, Maria do Socorro F. V.; ARAÚJO, Sandra Simone Moraes de. Josué de Castro: um olhar sobre o Recife. In MAGNO, Tânia Elias. (org,) Memória do Saber: Josué de Castro. Rio de Janeiro. Fundação Cervantes. 2012.

FREYRE, Gilberto. Guia prático, histórico e sentimental da cidade do Recife. $5^{\mathrm{a}}$ ed. São Paulo Global. 2007.

Assombrações do Recife Velho: algumas notas históricas e outras tantas folclóricas em torno do sobrenatural no passado recifense. São Paulo. Global. 2008.

INSTITUTO DO PATRIMÔNIO HISTÓRICO E ARTÍSTICO NACIONAL.- Recife: Bairro do Recife. Disponível em: http://portal.iphan.gov.br//uploads/publicacao/2 rota patrimonio bairro_do_recifepe.pd f. Acesso em: 30/05/2019.

KOSSOY, Boris. Fotografia e história. São Paulo. Ateliê Editorial. 2014.

LIMA, Rogério; FERNANDES, Costa Ronaldo (org). O imaginário da cidade. Brasília. UNB. São Paulo. Impressa Oficial do Estado. 2000.

NOGUEIRA, Maria Aparecida Lopes. A cidade imaginada ou o imaginário da cidade. In História, ciências, saúde. Volume 1. Recife. Maguinhos. Mar-jun/1998. p. 115-123.

REZENDE, Antônio Paulo. As múltiplas cidades de Calvino e Freyre. In Guia prático, histórico e sentimental da cidade do Recife. $5^{\text {a }}$ ed. São Paulo Global. 2007.

PINTO, Luiz Carlos. Bairro do Recife 100 anos depois: História de vencidos e de esquecimento. Disponível em http://marcozero.org/bairro-do_recife-100-anos-depois/ 
PROENÇA, Rogério Leite. Contra-Usos da Cidade: lugares e espaço público na experiência urbana contemporânea. Editora da Unicamp, Campinas-SP; Editora da UFS, Aracaju, 2004. p. 96-156.

YÁZIGI, Eduardo. O mundo das calçadas. São Paulo. Humanitas; Impresa Oficial do Estado. 2000.

Recebido: 30/01/2020

Aprovado: $15 / 07 / 2020$ 